\title{
Status of Osyris quadripartita in borena and west guji zones, oromia region, Ethiopia
}

\begin{abstract}
Osyris quadripartita is an evergreen, dioecious shrub or tree up to $7 \mathrm{~m}$ tall, root hemiparasite, is used for its scented wood and belongs to the family Santalaceae. It is most commonly known as East African Sandalwood, indigenous to east Africa. The tree is harvested from the wild for local use as a food, medicine and source of wood and materials. Osyris quadripartita is also used to extract essential oil. In Ethiopian, Osyris quadrrpartita, is an economically important plant species that occurs in most parts of the regions but its population status and associated plant species have not been studied in Borena and West Guji Zones, Oromia region, Ethiopia. Therefore, the objective of this study was to assess the population status of Osyris quadrrpartita and its associated plant species in the study areas. Accordingly, the study was conducted in four districts within the two zones. From five districts nine forest areas were selected purposively based on the distribution of Osyris quadripartita. The data was collected through vegetation survey, direct observation and local informants' interview. Systematic random sampling design was employed based on line transect approach for data collection from 29 quadrats, each with $20 \mathrm{~m} \mathrm{x} 20 \mathrm{~m}$ area at $100 \mathrm{~m}$ intervals. Majority of the respondents $(75 \%)$, particularly the elders and other knowledgeable community members living for a long period in the study areas were reported that Osyris quadripartita was used for traditional medicine and perfume, that prepared by women, locally called "Qaya". The rest respondents $(25 \%)$ were revealed that it used for local construction, firewood and income generation. Out of 29 quadrants of the study areas, in $19(65.52 \%)$, Osyris quadripartita was abundantly found. while, in 5 $(17.24 \%)$, rarely available and $5(17.24 \%)$, not found. Regarding, associated plant species, the highest number of species 19(24.1\%), was fabaceae family, followed by Anacardiaceae and Rutaceae each was contributed $4(5.1 \%)$. The result of this assessment study indicated that Osyris quadripartita was found somewhat abundantly in selected forest of Borena zone and rarely abundant in west Guji zone. Therefore, by raisin up awareness of local communities, it can be minimized the depletion of genetic resources and the cultivation of the plant should be also encouraged for future.
\end{abstract}

Keywords: osyris quadripartita, status, abundant, associated species
Volume 3 Issue 2 - 2019

\section{Tesfaye Bekele,Amare Seifu,Ashenafi Ayenew}

Genetic Resources Access and Benefit Sharing Directorate,

Ethiopian Biodiversity Institute (EBI), Ethiopia

Correspondence: Tesfaye Bekele, Genetic Resources Access and Benefit Sharing Directorate, Ethiopian Biodiversity Institute (EBI),Addis Ababa, Ethiopia, Email tesfayebekele44@gmail.com

Received: March 18,2019 | Published: April 19, 2019

\section{Introduction}

Osyris quadripartita is a synonymy of Osyris lanceolata Hochst \&Steud and belongs to the family Santalaceae. It is most commonly known as East African Sandalwood, ${ }^{1}$ indigenous to east Africa. It is an evergreen, dioecious shrub or tree up to $7 \mathrm{~m}$ tall, an obligate root hemi-parasite, meaning that it cannot complete its lifecycle without a host plant. Osyris quadripartita is monoecious, flowering from March to August or even later, September to February with fruits ripening between May and September. In some areas, the fruit is available throughout the year but most abundant from July to December. ${ }^{2}$ The height of the plant various depending on the soil type, climatic conditions and genetic variation. Accordingly, it has a wide geographic distribution in Africa from Algeria to Ethiopia, Tanzania and Kenya and South Africa. ${ }^{3}$ It is most commonly found in Gallery forest Juniperus, Podocarpus, Combretum and Dodonea woodland, Erica scrub, Acacia nilotica, Commiphora scrub, on rocky slopes or along the margins of dry forest, degraded woodland and scrub; 900 to-2900 m.a.s.l in areas with mean annual rainfall of 600 to $1600 \mathrm{~mm}$. Occurs in most Ethiopian regions. Besides, sporadically in rocky sites and along the margins of dry forests, evergreen bush land, grassland, and thickets at an altitude range of $900-2250 \mathrm{~m}$ above sea level. ${ }^{4,5}$

Osyris quadripartita is used for its scented wood and to extract essential oil. The tree is harvested from the wild for local use as a food, medicine and source of wood and materials. The wood is sold locally and traded internationally for its essential oil, which is used in making perfume. For instance, Roots and bark are used for tea and as a tonic in soup, fruits are edible. Especially children or herdsmen eat ripe fruits raw, with the seed discarded, only as an emergency food. Besides, root decoction is used to treat diarrhea, a decoction of the bark, heartwood is used to treat sexually transmitted diseases and anemia, and extracts from the plant can cure certain diseases, including the killer Hepatitis B. ${ }^{2}$

The wood is over-exploited in parts of its range despite legal protection. Its numbers have been greatly reduced by overexploitation of its roots, which are the source of an expensive essential oil. ${ }^{5-}$ 7 However, Sandalwood has captured the attention due to its overexploitation to meet international demand for its perfumery and medicinal products. The mode and scale of harvesting has made the tree to be locally endangered, which threatens not only the survival of the species, but also the sustainability of the trade in the species products. ${ }^{8,9}$ The exploitation of Osyris quadripartita from Africa could soon drive the species to extinction unless proper control measures are put in place to regulate international trade in the species. ${ }^{6,7}$

In Ethiopia, the population status of $O$. quadripartita is not well studied except the study by Amare Seifu et al., ${ }^{10}$ in selected districts of South Omo and Gamu Gofa Zones, SNNPR, Ethiopia. The result of this study indicated that most of the areas that Osyris quadripartita abundantly found were protected areas. Furthermore, the plant's poor 
natural regenerative power from seeds and root suckers, and its being dioecious may threatens the survival of the plant. On this regards the Ethiopian Biodiversity Institute (EBI) is responsible to conserve, sustainably utilized and fair and equitable sharing of benefit from the utilization of genetic resources. Therefore, the objectives of this study were to assess the population status and availability of Osyris quadripartita and associated species with it to keep up the sustainable utilization of the plant in selected nine forest areas. Such as (Qermso, Gaara Birbirsa, Dharito, Didera, Lakole, Surupa, Bada Magada ,Dugda Dawa and Suro Badiya) of Borena and west Guji Zones of Oromia Region, Ethiopia.

\section{Materials and methods}

\section{Description of the study area}

Borena zone is located between $3^{\circ} 36-6^{\circ} 38^{\prime}$ North latitude and $3^{\circ} 43^{\prime}$ - $39^{\circ} 30^{\prime}$ East longitude. Borena zone shares common boundaries with Guji zone in the east, Somali regional state in southeast, SNNPR in the north and west and one international boundary with Kenya. The capital city of the zone is Yabello, which is located at distance of $570 \mathrm{Km}$ south of Addis Ababa. ${ }^{11}$ Besides, West Guji Zone is one of the zones of the Oromia Region; it is located on the paved Addis Ababa-Moyale highway at the distance of $481 \mathrm{Km}$. It has a latitude and longitude of $5^{\circ} 34^{\prime} 59.99^{\prime \prime} \mathrm{N} 38^{\circ} 19^{\prime} 60.00^{\prime \prime} \mathrm{E}$ and an altitude of 1716 meters above sea level (Figure 1).

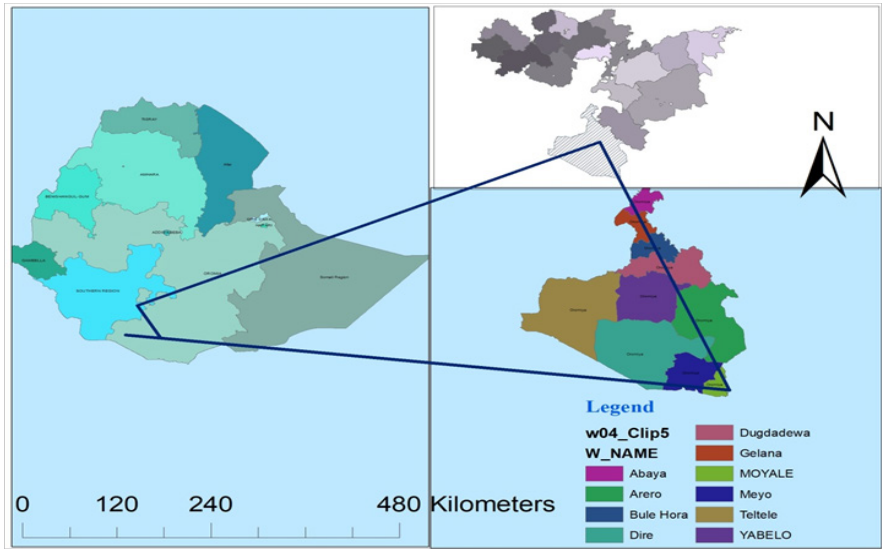

Figure I Administrative map of the study areas.

\section{Methods of data collections}

The study was conducted in Borena and West Guji Zones in four districts, two districts from each Zone. From the two Zones, the study was conducted only in four districts. Hence, Yabello, Dire, Bule Hora and Suro Barguda was selected to conduct this assessment study. From four districts eight forest areas (Gaara birbirsa, Dharito, Lakole, Didera, Qermso, Dhobdo, Suro Badiya and Bada Megada) were selected purposively based on the distribution of O.quadripartita.

These three ways of data collection were used:

\section{Direct observation and semi-structured questionnaires designed}

The researchers were also observed every forest patch if they were suspected the existence of O. quadripartita and check for presence/ absence. If the species was present, the researchers were estimated its abundance. Besides, elders and other knowledgeable community members in particular living for a long period in the areas and have knowledge about the plant were selected and interviewed.

\section{Vegetation survey}

The closure areas or forest patches identified by the help of informants or found during our random observation and where there seemed to be abundant Osyris quadripartita individuals, the researchers laid twenty-nine 20x20 plots and within each plot, the number of Osyris quadripartita present was counted so that abundance per hectare was estimated. The sampling method was based on line transect approach and systematic random sampling techniques using one transect line. The assessment was conducted in community forest, communal land and area closures. Two consecutive plots were separated from each other by $100 \mathrm{~m}$. In each plot, the number of O. quadripartita was recorded and the associated species also identified and recorded or assessed the abundance and availability of O. quadripartita.

\section{Methods of data analysis}

The collected data was analyzed by using SPSS (statistical package for social sciences) version 23. A descriptive statistical method was employed to analyze and summarize the data and to calculate percentages, frequency and mean.

\section{Result and discussions}

\section{Abundance of osyris quadripartita in selected forest of borena zone}

Elders and other knowledgeable community members in particular living for a long period of time in the areas and have well developed knowledge about their environment and called plant species in vernacular name were reported that Osyris quadripartita called "Wato" in vernacular name in the areas. Beside this, 75\% of them were described Osyris quadripartite used for traditional medicine and perfume (that prepared by women, locally called "Qaya"). In addition to this, most of respondents were stated that the plant used for local construction, firewood and for sell (income generation) in the zone. Out of a total 22 plots were laid, in $68.2 \%$, Osyris quadripartita was abundantly found, whereas, in $13.6 \%$, the plant was rarely available and in $18.2 \%$ of the plots, Osyris quadripartita was not found. In other hand, from 22 plots almost in all of the $15(68.18 \%)$ plots trees were dominated. In addition, during this surveying the newly Osyris species or not recorded before in Ethiopia was observed around Dirre wored near to Mega town and we were recorded and identified this species as Osyris compressa (Figure 2) (Table 1).

Osyris quadripartita is a potential industrial plant with very high content. In order to study abundance and areas of distribution field evaluation were carried out. Besides this, an altitude of collecting sites were varied and range between 1,250 and 2,050m.a.s.l. rather than protected areas there were no $O$. quadripartita counted in most unprotected open forests. This could be an indication of change in land use system and environmental degradation and, hence, loss of genetic resources of the species.

\section{Abundance of osyris quadripartita in selected forest of west guji zone}

In west Guji Zone, two forest areas (Bada Magada and Suro Barguda) were purposively selected based on the information 
obtained from the key informants. In these two forests 7 plots were laid, out of 7 plots in $4(57.1 \%)$ of the sites Osyris quadripartita was abundantly found, in 2 plots $(28.6 \%)$ the plant was relatively abundance and in only one plot the plant was not found. On the other hand, in 3 plots only Osyris compressa was found and most of them were trees. Similarly, in3 plots only Osyris quadripartita was found and both trees and saplings were found in these plots (Table 2). As we mentioned above the existence of Osyris compressa in Borena and West Guji zones was a newly identified plant species, which was not registered before in the Flora of Ethiopia and Eretria Volumes.

Table I Osyris quadripartita exploration sites in borena zone

\begin{tabular}{|c|c|c|c|c|c|c|c|c|c|}
\hline No & $\begin{array}{l}\text { Exploration } \\
\text { sites }\end{array}$ & Districts & Altitude & Latitude & Longitude & $\begin{array}{l}\text { Average } \\
\text { no. of } \\
\text { Osyris } \\
\text { per plot }\end{array}$ & $\begin{array}{l}\text { Present/ } \\
\text { Absent }\end{array}$ & Status & Remark \\
\hline I & $\begin{array}{l}\text { GaraBibirsa } \\
\text { (Obdo) I }\end{array}$ & Yabello & 2075 & $04^{0} 53$ '20.I”N & $038^{\circ} 02^{\prime}$ I $4.3^{\prime \prime} \mathrm{E}$ & No & Absent & Not found & Natural forest \\
\hline 2 & $\begin{array}{l}\text { GaraBibirsa } \\
\text { (Obdo) } 2\end{array}$ & Yabello & 2073 & $04^{0} 53^{\prime 2} 21.2^{\prime \prime N}$ & $038^{\circ} 02^{\prime}$ I 5.0”E & I & Present & Rare & O. compressa \\
\hline 3 & $\begin{array}{l}\text { Gara Bibirsa } \\
\text { (Obdo) } 3\end{array}$ & Yabello & 2086 & $04^{0} 53^{\prime 2} 22.2^{\prime \prime N}$ & $038^{\circ} 02^{\prime} \mid 2.7^{\prime \prime} E$ & 3 & Present & Rare & $\begin{array}{l}\text { O. compressa \& } 0 \text {. } \\
\text { Quadripartita }\end{array}$ \\
\hline 4 & Dhereto I & Yabello & 1705 & $04^{0} 47^{\prime} 23.7^{\prime \prime} \mathrm{N}$ & $038^{\circ} 09^{\prime}$ I9.4”'E & 25 & Present & Abundant & \\
\hline 5 & Dhereto 2 & Yabello & 1703 & $04^{\circ} 47^{\prime} 24.2^{\prime \prime} \mathrm{N}$ & $038^{\circ} 09^{\prime} \mid 8.3^{\prime \prime} \mathrm{E}$ & 30 & Present & Abundant & \\
\hline 7 & Dhereto 4 & Yabello & 1750 & 04047'27.7”N & $038^{\circ} 09^{\prime} \mid 6.7^{\prime \prime} E$ & 16 & Present & Abundant & \\
\hline 8 & Dhereto 5 & Yabello & 1756 & $04^{\circ} 47^{\prime} 29.0^{\prime \prime} \mathrm{N}$ & $038^{\circ} 09^{\prime} \mid 6^{6 . I ” E}$ & 15 & Present & Abundant & \\
\hline 9 & Dhereto 6 & Yabello & 1758 & $04^{\circ} 47$ '29.I”N & 038009'20.0”'E & 20 & Present & Abundant & \\
\hline 10 & Didera I & Yabello & 1530 & $04^{0} 47^{\prime} 42.3^{\prime \prime} \mathrm{N}$ & $038^{\circ} 25^{\prime} 36 . \mathrm{I}$ 'E & - & Absent & Not found & \\
\hline II & Didera & Yabello & 1457 & $04^{0} 47^{\prime} 50.1 ” \mathrm{~N}$ & $038^{\circ} 23^{\prime 2} 23.3^{\prime \prime} \mathrm{E}$ & I & Present & Rare & \\
\hline 12 & Dire (Lakole) I & Dirre & 1852 & $04^{\circ} 06^{\prime} 45.7^{\prime \prime} \mathrm{N}$ & $038^{\circ}$ I 7’23.5”E & 23 & Present & Abundant & \\
\hline 13 & Dire (Lakole) 2 & Dirre & 1852 & $04^{\circ} 06^{\prime} 44.7^{\prime \prime} \mathrm{N}$ & $038^{\circ}$ I $7^{\prime} \mid 4.0^{\circ} \mathrm{E}$ & 18 & Present & Abundant & $\begin{array}{l}\text { Trees with DBH } 6-8 \mathrm{~cm} \\
\text { O. compressa all are trees }\end{array}$ \\
\hline 14 & Dire (Lakole) 3 & Dirre & 1856 & $04^{\circ} 06^{\prime} 43.0^{\prime \prime} \mathrm{N}$ & 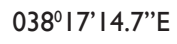 & 20 & Present & Abundant & \\
\hline 15 & Dire (Lakole) 4 & Dirre & 1806 & $04^{\circ} 07^{\prime} \mid 4.2^{\prime \prime} \mathrm{N}$ & $038^{\circ}$ I 7 'IO.4”E & 17 & Present & Abundant & \\
\hline 16 & Dire (Lakole) 5 & Dirre & 1799 & $04^{\circ} 07^{\prime} \mid 5.8^{\prime \prime} \mathrm{N}$ & 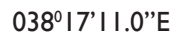 & 21 & Present & Abundant & \\
\hline 17 & Dire (Lakole) 6 & Dirre & $180 \mid$ & $04^{0} 07^{\prime} \mid 6.2^{\prime \prime} \mathrm{N}$ & $038^{\circ}$ I7'I2.I’'E & 28 & Present & Abundant & \\
\hline 18 & Dire (Lakole) 7 & Dirre & 1795 & $04^{\circ} 07^{\prime} \mid 6.8^{\prime \prime} \mathrm{N}$ & 038 I I'II.7’'E & 20 & Present & Abundant & \\
\hline 19 & Dire (Lakole) 8 & Dirre & 1777 & $04^{\circ} 07^{\prime} \mid 8.8^{\prime \prime N}$ & $038^{\circ}$ I 7’08.7’'E & 15 & Present & Abundant & \\
\hline 20 & Dire (Lakole) 9 & Dirre & 1776 & $04^{\circ} 07^{\prime} \mid 8.3^{\prime \prime N}$ & 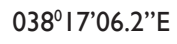 & 25 & Present & Abundant & \\
\hline 21 & $\begin{array}{l}\text { Qermso } \\
\text { (Dhobdo) }\end{array}$ & Yabello & 1897 & $04^{\circ} 54^{\prime} 00.0^{\prime \prime} \mathrm{N}$ & 0380'31.0”'E & No & Absent & Not found & \\
\hline 22 & $\begin{array}{l}\text { GaraBibirsa } \\
\text { (Dhobdo) I }\end{array}$ & Yabello & 2075 & $04^{0} 53$ '20.I”N & 0380.' '4.3”E & No & Absent & Not found & \\
\hline
\end{tabular}


Table 2 O.quadripartita exploration sites in west guji zone, bule hora (b) and suro barguda (s) district

\begin{tabular}{|c|c|c|c|c|c|c|c|c|c|}
\hline No. & $\begin{array}{l}\text { Exploration } \\
\text { sites }\end{array}$ & Districts & Altitude & Latitude & Longitude & $\begin{array}{l}\text { Average } \\
\text { no. of } \\
\text { Osyris/per } \\
\text { plot }\end{array}$ & $\begin{array}{l}\text { Present/ } \\
\text { Absent }\end{array}$ & Status & Remark \\
\hline I. & BadaMagada & B/Hora & 1970 & $05^{\circ} 29^{\prime} \mid 4.4^{\prime \prime} \mathrm{N}$ & $038^{\circ}$ I 5'38.0”'E & No & Absent & Not found & $\begin{array}{l}\text { Informant report } \\
\text { indicated it found } \\
\text { at the back of } \\
\text { forest like kola }\end{array}$ \\
\hline 2. & Suro Badiya I & S/Barguda & 1895 & $05^{0} 34^{\prime} 00.9^{\prime \prime} \mathrm{N}$ & 038이일.2”E & 7 & Present & $\begin{array}{l}\text { Relatively } \\
\text { abundance }\end{array}$ & O. qadripartita \\
\hline 3. & Suro Badiya2 & S/Barguda & 1885 & $05^{0} 34^{\prime} 00.5^{\prime \prime} \mathrm{N}$ & $038^{\circ} 00^{\prime} 33$. I"'E & 15 & Present & Abundant & $\begin{array}{l}\text { Tree and Saplings } \\
\text { O. qadripartita }\end{array}$ \\
\hline 4. & Suro Badiya3 & S/Barguda & 1884 & $05^{0} 34^{\prime} 02.5^{\prime \prime} \mathrm{N}$ & $038^{\circ} 00^{\prime} 32.7^{\prime \prime} \mathrm{E}$ & 8 & Present & $\begin{array}{l}\text { Relatively } \\
\text { Abundant }\end{array}$ & $\begin{array}{l}\text { Sapling (All } \\
\text { Female) }\end{array}$ \\
\hline 5. & Suro Badiya4 & S/Barguda & 1912 & $05^{\circ} 33^{\prime} 40.7^{\prime \prime} \mathrm{N}$ & $038^{\circ} 02^{\prime} 35.9^{\prime \prime} \mathrm{E}$ & 20 & Present & Abundant & \\
\hline 6. & Suro Badiya5 & S/Barguda & 1923 & $05^{\circ} 33^{\prime} 40.5^{\prime \prime} \mathrm{N}$ & $038^{\circ} 02^{\prime} 34.3^{\prime \prime} \mathrm{E}$ & 10 & Present & Abundant & $\begin{array}{l}\text { All Tree and Osyris } \\
\text { compressa }\end{array}$ \\
\hline 7. & Suro Badiya5 & S/Barguda & 1919 & $05^{\circ} 33^{\prime} 42.8^{\prime \prime} \mathrm{N}$ & $038^{\circ} 02^{\prime} 34$. I"E & 12 & Present & Abundant & \\
\hline
\end{tabular}
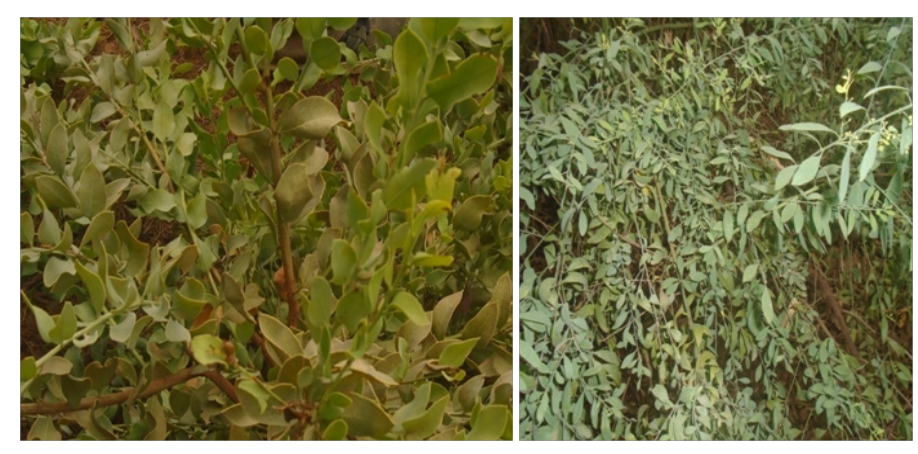

he capacity to fix atmospheric nitrogen through their root nodules. Whereas, the pollination biology dioecious woody species has often shown sexual dimorphism and differences in resources allocation between female and male. Accordingly, most species in the members of Anacardiaceae family are dioecious or polygamous and bear manyflowered inflorescences. Therefore, flowers possess nectary organs, they need cross-pollinated and are evidently Entomophilous. In addition, Osyris quadripartita and species of anacardiaceae family similar reproduction style and share in a deciduous habit and widely distribute semiarid conditions in lowland and highland woodlands of Moist and Wet Weyna Dega and Dega agro -climatic zones of Ethiopia.

Figure 2 Morphological appearance of Osyris species, A, Osyriscompressa, B, Osyrisquadripartita.

\section{Associated species and families with osyris quadripartita}

In different Exploration sites, Osyris quadripartita was found associated with varieties of plant species. Out of 78 plant species recorded from 29 sites, which belongs to 33 families and 61 genera. Fabaceae, family which was found to be represented by the highest number of species 19(24.1\%); followed by Anacardiaceae and Rutaceae each was contributed 4(5.1\%), whereas, (Burseraceae, Capparidaceae, Combretaceae, Euphorbiaceae, Oleaceae, Rubiaceae, Vitaceae and Asteraceae) each individual were represented by 3 species $(3.79 \%)$ and the rest were indicated in (Table 3). Similarly, we were observed that Osyris quadripartita was mostly associated with Acacia species, Euclea racemosa, Dodonaea angustifolia, Combretum molle, Rhus spp, Canthium lactescens, Cadaba farinose, Dichrostachys cinerea, Tephrosia emeroides and Euclea divinorum in these study areas. Since, most of those plant species associated with $O$. quadripartita were widespread in a variety of habitats, from arid marginal areas in Dry and Moist Kola, dry woodland, bushland, semidesert, scrub, riverine forest and marginal arid areas or on forest edges. They tolerates forest or grass fires well. Likewise, O. quadripartita prefers a well-drained, humus-rich clay or loamy soil in the wild and hemi-parasitic plant due to this it might be mostly occur friendly with similar of these plant species. ${ }^{10}$ It also occurred with legume plant species that have play vital role in increasing soil fertility as they have
Table 3 Composition of associated plants with Osyris quadripartite

\begin{tabular}{lllll}
\hline No & Family & $\begin{array}{l}\text { number } \\
\text { of } \\
\text { species }\end{array}$ & $\begin{array}{l}\text { number } \\
\text { of } \\
\text { genera }\end{array}$ & $\begin{array}{l}\text { (\%) contribution to } \\
\text { the total number of } \\
\text { species }\end{array}$ \\
\hline I & Sapindaceae & I & I & I.265822785 \\
2 & Acanthaceae & I & I & 1.265822785 \\
3 & Aloaceae & I & I & 1.265822785 \\
4 & Amaryllidaceae & I & I & 1.265822785 \\
5 & Anacardiaceae & 4 & 3 & 5.063291139 \\
6 & Apiaceae & I & I & 1.265822785 \\
7 & Apocynaceae & 2 & 2 & 2.53164557 \\
8 & Asparagaceae & I & I & 1.265822785 \\
9 & Asteraceae & 3 & 2 & 3.797468354 \\
I0 & Balanitaceae & I & I & 1.265822785 \\
II & Burseraceae & 3 & I & 3.797468354 \\
12 & Capparidaceae & 3 & 3 & 3.797468354 \\
I3 & Combretaceae & 3 & 2 & 3.797468354 \\
I4 & Cupressaceae & I & I & 1.265822785 \\
\hline & & & &
\end{tabular}


Table Continued

\begin{tabular}{|c|c|c|c|c|}
\hline No & Family & $\begin{array}{l}\text { number } \\
\text { of } \\
\text { species }\end{array}$ & $\begin{array}{l}\text { number } \\
\text { of } \\
\text { genera }\end{array}$ & $\begin{array}{l}\text { (\%) contribution to } \\
\text { the total number of } \\
\text { species }\end{array}$ \\
\hline 15 & Ebenaceae & 2 & I & 2.53164557 \\
\hline 16 & Euphorbiaceae & 3 & 3 & 3.797468354 \\
\hline 17 & Fabaceae & 19 & 9 & 24.05063291 \\
\hline 18 & Fabaeae & I & I & I.265822785 \\
\hline 19 & Iridaceae & I & I & I.265822785 \\
\hline 20 & Meliaceae & I & I & I.265822785 \\
\hline 21 & Oleaceae & 3 & 3 & 3.797468354 \\
\hline 22 & Polygalaceae & 1 & I & I.265822785 \\
\hline 23 & Proteaceae & 1 & 1 & I.265822785 \\
\hline 24 & Rhamnaceae & 2 & 2 & 2.53164557 \\
\hline 25 & Rubiaceae & 3 & 3 & 3.797468354 \\
\hline 26 & Rutaceae & 4 & 3 & 5.063291139 \\
\hline 27 & Sapindaceae & 2 & 2 & 2.53164557 \\
\hline 28 & Simaroubaceae & 2 & 2 & 2.53164557 \\
\hline 29 & Solanaceae & I & I & I.265822785 \\
\hline 30 & Sterculiaceae & I & I & I.265822785 \\
\hline 31 & Thymelaeaceae & 1 & I & I.265822785 \\
\hline 32 & Tiliaceae & 2 & 1 & 2.53164557 \\
\hline 33 & Vitaceae & 3 & 3 & 3.797468354 \\
\hline Total & & 79 & 61 & 100 \\
\hline
\end{tabular}

\section{Conclusion and recommendations}

We conclude that change in land use system and environmental degradation and, hence, loss of genetic resources of the species. However, the result of our assessment was indicated that Osyris quadripartita was found mostly abundant in Borena zone and relatively abundant in west Guji zone. Nevertheless, the abundance of the plant was found under protected areas except Dharito, which was found in natural forest (under human interference) or not protected in Borena zone. Similarly, in west Guji zone it was found under protected natural forests. Furthermore, we recommend raising up awareness of local communities on the value of genetic resources and ecological consequences of its loss and device mechanisms by which human impacts can be minimized through training; desiccation and consultation with the local communities for continuously manage and preserve natural resources and the cultivation of the plant should be encouraged for future.

\section{Acknowledgments}

The communities of Borena and West Guji Zone, Oromia Regional State who support us during assessment are gratefully acknowledged. We are grateful to Ethiopian Biodiversity Institute (EBI) for their financial and material support during fieldwork. We are also grateful to administrators of Borena and West Guji zones.

\section{Conflicts of interest}

The author declares there is no conflicts of interest.

\section{References}

1. Kokwaro JO. Osyris lanceolata. In: Medicinal Plants of East Africa, 3rd Edn. University of Nairobi Press, Nairobi. 2009.

2. Orwa C, A Mutua, Kindt R, et al. Agroforestry Database: a tree reference and selection guide version 4.0. 2010

3. Teixeira da Silva JA, Kher MM, Soner D, et al. African Sandalwood or Nepalese Sandalwood: a Brief Synthesis. Notulae Science Biologicae. 2016;8(1):57-61.

4. Giathi G, Machua J, Ndegwa W, et al. Developing technology for mass propagation of Osyris lanceolata (East African Sandalwood): Through rooting, stem cutting. KEFRI. 2011.

5. Kamondo B, Chahilu O, Gitehi G, et al. Collection handling and germination of Osyris lanceolata seeds: Guidelines for farmers and extension agents. Kenya. 2012.

6. William Omondi Oloo. A very useful plant, Osyris lanceolata, is at risk of extinction due to overexploitation. Kew News. 2012.

7. CITES. Sixteenth meeting of the Conference of the Parties, consideration of proposals for amendment of appendices I and II, Bangkok. 2013.

8. Kamondo B, Giathi G, Osore C, et al. Growing of East African Sandal wood. Guidelines for Tree Growers, Kenya Forestry Research Institute, KEFRI, Nairobi. 2014

9. Herrera C. The fruiting ecology of Osyris quadripartita: individual variation and evolutionary potential. Ecology. 1988;69(1):233-249.

10. Amare Seifu, Tesfay Bekele, Ashenafi Ayenew. Abundance and socio economic importance of Osyris quadripartita in South Omo and GamU Gofa zones, SNNPR, Ethiopia. International Journal of Modern Pharmaceutical Research. 2018;2(4):15-21.

11. CSA. Ethiopian Statistical Abstract. CSA, Addis Ababa, Ethiopia. 2008. 